\title{
Sulindac in Established Experimental Diabetes: a Follow-up Study
}

\author{
Paul van der Sloot, Andrew Mizisin and Douglas Zochodne
}

\begin{abstract}
Background: In two previous studies we have demonstrated prevention of electrophysiological abnormalities of nerve in experimental STZ (streptozotocin)-induced diabetes (ED) of rats using nonsteroidal anti-inflammatory agents: indomethacin and sulindac. Sulindac might benefit ED because it inhibits both cyclo-oxygenase and aldose reductase. Methods: In this work, we examined whether 1 month of sulindac treatment reversed or improved established biochemical and electrophysiological abnormalities in experimental diabetes of 3 months duration. Sulindac-treated diabetic rats $(6.0 \mathrm{mg} / \mathrm{kg}$ $5 / 7$ days weekly by gavage) were compared to untreated diabetics, nondiabetic controls and sulindac treated control rats. Results: Diabetic rats developed slowing of conduction velocity in caudal sensory, sural sensory, caudal motor and sciatic tibial motor fibers. Sulindac improved caudal motor and, to a lesser extent sural sensory conduction but not caudal sensory or sciatic tibial motor conduction. Sulindac did not alter sciatic sugars or polyols. Conclusions: Sulindac provided modest improvement in some indices of experimental neuropathy in this reversal study, but there was less efficacy than in the preventative study. Reversal paradigms should be examined in all experimental therapies for diabetic neuropathy.
\end{abstract}

RÉSUMÉ: Le sulindac dans le diabète expérimental établi: suite d'observation. Introduction: Dans nos deux études antérieures, nous avons démontré qu'on pouvait prévenir les anomalies électrophysiologiques chez le rat, dont le diabète expérimental (DE) a été induit par la streptozotocine, au moyen d'agents anti-inflammatoires non stéroïdiens: l'indométhacine et le sulindac. Le sulindac pourrait être bénéfique dans le DE parce qu'il inhibe la cyclo-oxygénase et l'aldose-réductase. Méthodes: Nous avons évalué si un traitement d'un mois par le sulindac pouvait corriger ou améliorer des anomalies biochimiques et électrophysiologiques établies depuis 3 mois dans le DE. Des rats diabétiques traités par le sulindac $(6.0 \mathrm{mg} / \mathrm{kg}$ administré par gavage $5 / 7$ jours par semaine) ont été comparés à des rats diabétiques non traités, à des contrôles non diabétiques et à des contrôles traités au sulindac. Résultats: Les rats diabétiques ont développé un ralentissement de la vitesse de conduction au niveau des fibres sensitives caudales et surales, et des fibres motrices caudales et sciatiques tibiales. Le sulindac a amélioré la conduction motrice caudale et, à un degré moindre, la conduction sensitive surale. Aucune amélioration de la conduction sensitive caudale ou de la conduction motrice sciatique tibiale n'a été observée. Le sulindac n'a pas modifié les sucres ou les polyols sciatiques. Conclusions: Le sulindac produit une légère amélioration de certains marqueurs de la neuropathie expérimentale dans cette étude de régression, mais s'est avéré moins efficace que dans l'étude préventive. Les paradigmes de correction des lésions devraient être examinés dans toutes les thérapies expérimentales de la neuropathie diabétique.

Can. J. Neurol. Sci. 1995; 22: 198-201

In previous work, we demonstrated that the oral administration of sulindac, a nonsteroidal anti-inflammatory agent used in human arthritis, prevented motor and sensory conduction deficits in experimental STZ (streptozotocin)-induced diabetes of rats. ' Postulated mechanisms of this benefit included its possible role as an aldose reductase inhibitor, with or without additional benefits from inhibition of cyclo-oxygenase. ${ }^{1-4}$ Sulindac was given at the outset of diabetes.

In this work we evaluated the impact of sulindac treatment on established STZ diabetes in rats of 12 weeks duration to determine possible reversal of electrophysiological abnormalities and its impact on the polyol pathway.

\section{METHODS}

Rats used were male Sprague-Dawley rats of initial weight approximately 300 grams, raised on sawdust covered plastic floored cages with free access to rat chow and water. Diabetes was induced by a single injection of streptozotocin (STZ; 65 $\mathrm{mg} / \mathrm{kg}$ ip) with selection only of rats with hyperglycemia greater than or equal to $16.0 \mathrm{mmol} / \mathrm{L}$ throughout the experiment. Control nondiabetic rats received the citrate buffer STZ carrier only. The model was identical to that used in previous studies in our laboratory. ${ }^{1.5}$ Glucose levels were measured from the caudal vein on whole blood using a glucometer (AccuChek IIm; Boehringer Mannheim, Canada; Dorval, Quebec) and confirmed using fresh plasma and a glucose oxidase method (Ektachem DT60 II analyzer; Kodak; Rochester, NY). Electrophysiological

From the Department of Clinical Neurosciences, University of Calgary, Calgary. RECEIVED DECEMBER 21, 1994. ACCEPTED IN FINAL. FORM MARCH 29, 1995. Reprint requests 10: Dr. D.W. Zochodne, University of Calgary, Department of Clinical Neurosciences, 3330 Hospital Drive N.W., Calgary, Alberta. Canada T2N 4NI 
recordings were made at 8,12 and 16 weeks from sciatic-tibial motor fibers, caudal motor and caudal sensory fibers in vivo with the near nerve subcutaneous temperature maintained at $37^{\circ}$ C. At the endpoint of 16 weeks, the sural nerve was resected for measurements of in vitro sensory conduction. Details of these electrophysiological techniques have been previously published. ${ }^{6}$ After the electrophysiological measurements, the sciatic nerves were resected and fast frozen in liquid nitrogen cooled isopentane, then stored at $-70^{\circ} \mathrm{C}$, and later shipped on dry ice to the University of California, San Diego for sugar and polyol measurements by gas chromatography (AM). Technical details of the measurement procedures have been published. ${ }^{7}$

Sulindac treatment was begun $(6 \mathrm{mg} / \mathrm{kg}$ suspended in $0.5 \%$ methylcellulose and $0.2 \%$ sodium benzoate and given by gavage tube five times weekly) following the electrophysiological studies at 12 weeks after STZ or citrate injection and continued for 4 weeks to endpoint. Four groups of rats were studied: nondiabetic controls, nondiabetic controls given sulindac, untreated diabetics and diabetics given sulindac. Cataract development was graded by visual inspection of each eye: 0 -absent, 1 -mild changes, 2 -dense cataract (maximum score-4). Results were compared using a oneway analysis of variance (ANOVA) at each time point with post ANOVA comparisons performed using a two tailed student's ttest. The null hypothesis was rejected for $\mathrm{p} \leq 0.05$.

\section{Results}

Diabetic rats developed cataracts, gained less weight than nondiabetics and had elevated glycated hemoglobin levels (Table 1). Electrophysiological abnormalities in diabetic rats after 16 weeks were slowing of conduction velocities in caudal sensory fibers, caudal motor fibers, sciatic-tibial motor fibers and sural sensory fibers (Table 2). Diabetic sciatic nerves had elevated levels of glu- cose, fructose and sorbitol with reduced myo-inositol (Table I).

Sulindac treatment did not influence hyperglycemia, or glycated hemoglobin values. Sulindac treated diabetic rats weighed less than untreated diabetics. There was a nonsignificant trend toward a lower cataract score following sulindac treatment but no impact on sciatic levels of sugars or polyols. Sulindac had no significant impact on conduction velocity slowing of diabetic rats in caudal sensory fibers or sciatic-tibial motor fibers. Sulindac treatment resulted in a rise in conduction velocity in caudal motor fibers rendering values higher than untreated diabetic rats and not significantly different than control values by the 16 week endpoint. In sural fibers recorded in vitro, at 16 weeks there was also an improvement in conduction velocity of sulindac treated diabetic rats such that values were not significantly different than those of controls. Sulindac had no influence on electrophysiological or biochemical measurements in nondiabetic rats (data not shown).

\section{Discussion}

Experimental therapy for diabetic neuropathy probably should fulfill several criteria before being applied to human clinical trials. The agent should prevent neuropathic deficits, but more importantly, be able to prevent their progression after they already exist. Of the large number of experimental agents tested using the STZ rat model of diabetes, only a few have undergone both preventative and reversal testing paradigms. ${ }^{8-10}$ Interesting discrepancies may occur comparing these types of evaluations. Sulindac, of three nonsteroidal anti-inflammatory agents tested in STZ diabetes (sulindac, piroxicam and indomethacin) is the first to be subjected to a reversal paradigm. ${ }^{1.5 .11}$ Reversal of established electrophysiological abnormalities in diabetes by sulindac was less impressive than its preventative action. Of

Table 1: Endpoint Weights, Biochemical Measurements.

\begin{tabular}{|c|c|c|c|}
\hline \multirow{2}{*}{$\begin{array}{l}\text { Measurement } \\
\text { Final weight (g) }\end{array}$} & \multirow{2}{*}{$\frac{\begin{array}{c}\text { Controls (n) } \\
\text { (Citrate) }\end{array}}{569 \pm 13(17)}$} & $\begin{array}{c}\text { Diabetics (n) } \\
\text { (Untreated) }\end{array}$ & $\begin{array}{l}\text { Diabetics Plus } \\
\text { Sulindac (n) }\end{array}$ \\
\hline & & $346 \pm 24(13)$ & $278 \pm 13(15)^{a}$ \\
\hline Plasma glucose (mmol/L) & $6.6 \pm 0.2$ & $26.0 \pm 1.0$ & $25.5 \pm 1.3^{b}$ \\
\hline Glycated $\mathrm{Hb}(\%)$ & $6.0 \pm 1.7(5)$ & $15.2 \pm 2.8(6)$ & $14.4 \pm 1.3(5)^{\mathrm{c}}$ \\
\hline Cataract score & & $4.3 \pm 0.6$ & $3.6 \pm 0.6$ \\
\hline \multicolumn{4}{|l|}{ - } \\
\hline Glucose & $9.81 \pm 0.81$ & $40.6 \pm 3.3$ & $44.6 \pm 3.2^{d}$ \\
\hline Sorbitol & $1.25 \pm 0.24$ & $4.74 \pm 0.81$ & $4.41 \pm 0.41^{c}$ \\
\hline Fructose & $3.14 \pm 0.28$ & $15.6 \pm 1.1$ & $15.1 \pm 0.7^{r}$ \\
\hline myo-Inositol & $9.92 \pm 0.44$ & $6.15 \pm 0.43$ & $7.00 \pm 0.51^{8}$ \\
\hline Sciatic water content ( $\mathrm{mg} / \mathrm{mg}$ dry weight) & $2.02 \pm 0.09$ & $2.19 \pm 0.12$ & $2.04 \pm 0.05$ \\
\hline
\end{tabular}

Results are means \pm s.e.m.

$*_{n}=10$ each group

a $p<0.0001$ (ANOVA); ND vs. D, D $+S p<0.0001 ; D$ vs. $D+S p=0.01$

${ }^{\mathrm{b}} \mathrm{p}<0.0001$ (ANOVA); ND vs. D, D $+\mathrm{S} \mathrm{p}<0.0001$

${ }^{c} p<0.02$ (ANOVA); ND vs. $D, D+S p<0.03$

${ }^{d} p<0.0001$ (ANOVA); ND vs. D, D $+S p<0.0001$

${ }^{c} \mathrm{p}<0.0001$ (ANOVA); ND vs. D, D $+S \mathrm{p}<0.001$

${ }^{r} p<0.0001$ (ANOVA); ND vs. D, D + S p $<0.0001$

g $p<0.0001$ (ANOVA); ND vs. D, D $+S p<0.0005$

ND - nondiabetics; D - diabetics; D + S - diabetics + Sulindac

NB: Control plus sulindac group data not shown 
Table 2: Electrophysiological Results.

\begin{tabular}{|c|c|c|c|}
\hline Measurement & $\begin{array}{l}\text { Nondiabetics } \\
\text { (Citrate) }\end{array}$ & $\begin{array}{c}\text { Diabetics } \\
\text { (Untreated) }\end{array}$ & $\begin{array}{c}\text { Diabetics Plus } \\
\text { Sulindac (wks } 12-16)\end{array}$ \\
\hline \multicolumn{4}{|c|}{12 weeks } \\
\hline \multicolumn{4}{|l|}{ Caudal motor } \\
\hline $\mathrm{CV}(\mathrm{m} / \mathrm{s})$ & $40.4 \pm 0.8(20)$ & $37.8 \pm 1.3(15)$ & $38.3 \pm 0.9(15)$ \\
\hline Amp $(m V)$ & $8.1 \pm 0.6$ & $6.6+0.8$ & $5.9 \pm 0.7$ \\
\hline $\operatorname{Amp}(\mathrm{uV})$ & $53 \pm 3$ & $56 \pm 4$ & $59 \pm 4$ \\
\hline \multicolumn{4}{|c|}{ Sciatic-tibial motor } \\
\hline $\mathrm{CV}(\mathrm{m} / \mathrm{s})$ & $50.4 \pm 1.4$ & $44.7 \pm 1.1$ & $46.5 \pm 1.6^{\mathrm{b}}$ \\
\hline $\operatorname{Amp}(\mathrm{mV})$ & $9.8 \pm 0.6$ & $9.9 \pm 0.7$ & $10.6 \pm 0.6$ \\
\hline \multicolumn{4}{|c|}{16 weeks } \\
\hline \multicolumn{4}{|l|}{ Caudal sensory } \\
\hline $\mathrm{CV}(\mathrm{m} / \mathrm{s})$ & $58.5 \pm 1.0$ & $53.1 \pm 1.3$ & $54.2 \pm 1.0^{\mathrm{e}}$ \\
\hline $\operatorname{Amp}(\mathrm{uV})$ & $72 \pm 2$ & $63 \pm 7$ & $71 \pm 6$ \\
\hline \multicolumn{4}{|c|}{ Sciatic-tibial motor } \\
\hline $\mathrm{CV}(\mathrm{m} / \mathrm{s})$ & $52.7 \pm 1.7$ & $47.9 \pm 1.2$ & $45.6 \pm 1.2^{f}$ \\
\hline Amp $(\mathrm{mV})$ & $11.1 \pm 0.9$ & $11.3 \pm 1.3$ & $13.7 \pm 1.1$ \\
\hline \multicolumn{4}{|c|}{ Sural in-vitro sensory } \\
\hline $\mathrm{CV}(\mathrm{m} / \mathrm{s})$ & $60.8 \pm 1.4$ & $53.6 \pm 2.3$ & $56.4 \pm 1.3 \mathrm{~g}$ \\
\hline $\operatorname{Amp}(\mathrm{mV})$ & $1.4 \pm 0.2$ & $2.0 \pm 0.2$ & $2.5 \pm 0.6$ \\
\hline
\end{tabular}

Results are means \pm s.e.m., N, ND, D + S - see Table 1

" $p=0.004$ (ANOVA); ND vs. D, D $+S p<0.04$

${ }^{\mathrm{b}} \mathrm{p}=0.015$ (ANOVA); ND vs. $\mathrm{D}, \mathrm{D}+\mathrm{S} \mathrm{p} \leq 0.05$

${ }^{c} p=0.0003$ (ANOVA); ND vs. $D p=0.0001 ; D$ vs. $D+S p<0.03$

$\mathrm{d} p=0.03$ (ANOVA); ND vs. $D p=0.01 ; N D$ vs. $D+S p$ NS

c $p=0.002$ (ANOVA); ND vs. D, D $+S p<0.01$

${ }^{\prime} p=0.003$ (ANOVA); ND vs. D, D $+S p<0.03$

${ }^{g} p=0.015$ (ANOVA); ND vs. $D, p=0.005 ; N D$ vs. $D+S$ NS

NB: control plus sulindac group data not shown

two motor and two sensory territories tested, benefits were only observed in one each of these territories. This indicates that once neuropathic abnormalities have developed, they may be more difficult to reverse. Inhibition of cyclo-oxygenase to reduce thromboxane vasoconstriction and platelet aggregation, may be the mechanism of sulindac's preventative role. ${ }^{12}$ With sulindac, we did not observe the worsening in conduction velocity in control or diabetic rats suggested by Cameron et al. ${ }^{13.14}$ to result from inhibition of prostacyclin synthesis by flurbiprofen. In human clinical trials for stroke or other thrombotic disorders cyclo-oxygenase inhibition has not been associated with exacerbations attributable to prostacyclin deficiency.

No impact on the polyol pathway was observed following sulindac treatment despite previous reports suggesting that sulindac was an important aldose reductase inhibitor in human lens with a potency approaching that of sorbinil. ${ }^{2,3}$ Despite the short duration of sulindac treatment in the present work, some improvement in this pathway would have been expected if its action is through this mechanism.
An equally important criterion that should be applied to testing of experimental agents in diabetes is safety. There are important concerns in applying nonsteroidal anti-inflammatory agents in human diabetic subjects including risks of gastrointestinal hemorrhage and possible worsening of diabetic nephropathy. ${ }^{15}$ Although many diabetic patients use these agents for arthritic conditions, neuropathy therapy would require long term and continuous use. Although we do not advocate an abandonment of this therapeutic approach, it may have to be considered in conjunction with prophylaxis against gastrointestinal inflammation and ulceration. This consideration is not unique to this potential group of therapeutic agents in neuropathy. For example, similar concerns should be applied to a large number of vasoactive agents being tested in the STZ model for amelioration of diabetic nerve conduction abnormalities. ${ }^{10,16,17}$ These approaches may fail to consider risks in diabetic patients from autonomic neuropathy and postural hypotension-related falls, myocardial ischemia and cerebral hypoperfusion that would be exacerabated by the superimposition of vasodilating agents. 
Based on the results of the current work, we suggest a cautious approach in considering the use of nonsteroidal antiinflammatory agents for human trials of diabetic neuropathy. Our findings suggest that enthusiasm for new treatments should be tempered by rigorous preventative and reversal trials in an appropriate model and careful clinical thoughts about potential safety, should the agent look promising.

\section{ACKNOWLEDGEMENTS}

Brenda Boake and Heather Price provided expert secretarial assistance. PVS worked as a summer student sponsored by the Alberta Heritage Foundation for Medical Research (AHFMR). DWZ is a Medical Scholar of AHFMR and has received support from the Medical Research Council of Canada. Merck-Frosst kindly provided samples of sulindac.

\section{REFERENCES}

1. Zochodne DW, Ho LT. The influence of sulindac on experimental streptozotocin-induced diabetic neuropathy. Can J Neurol Sci 1994; 21: 194-202.

2. Sharma YR, Cotlier E. Inhibition of lens and cataract aldose reductase by protein-bound anti-rheumatic drugs: salicylate, indomethacin, oxyphenbutaxone, sulindac. Exp Eye Res 1982; 35: 21-27.

3. Chaudhry PS, Cabrera J, Juliani HR, Varma SD. Inhibition of human lens aldose reductase by flavonoids, sulindac and indomethacin. Biochem Pharmacol 1983; 32: 1995-1998.

4. Brogden RN, Heel RC, Speight TM, Avery GS. Sulindac: a review of its pharmacological properties and therapeutic efficacy in rheumatic diseases. Drugs 1978; 16:97-114.

5. Zochodne DW, Ho LT. The influence of indomethacin and guanethidine on experimental streptozotocin diabetic neuropathy. Can J Neurol Sci 1992; 19:433-441.

6. Zochodne DW, Ward KK, Low PA. Guanethidine adrenergic neuropathy: an animal model of selective autonomic neuropathy. Brain Res 1988; 461: 10-16.
7. Mizisin AP, Kalichman MW, Calcutt NA, Myers RR, Powell HC. Decreased endoneurial fluid electrolytes in normal rat sciatic nerve after aldose reductase inhibition. J Neurol Sci 1993; 116:67-72

8. Cameron NE, Cotter MA, Robertson S. The effect of aldose reductase inhibition on the pattern of nerve conduction deficits in diabetic rats. Q J Exp Physiol 1989; 74: 917-926.

9. Merry AC, Kamijo M, Lattimer SA, Ristic H, Sima AAF. Long term prevention and intervention effects of acetyl-l-carnitine on diabetic neuropathy in BB/W-Rats. Diabetes 1994; 43 (Suppl 1): 108A.

10. Kappelle AC, Bravenboer B, van Buren T, et al. Amelioration by the $\mathrm{Ca} 2+$ antagonist, nimidipine of an existing neuropathy in the streptozotocin-induced, diabetic rat. $\mathrm{Br} \mathrm{J}$ Pharmacol 1993; 108: 780-785.

11. Parry GJ, Kozu H. Piroxicam may reduce the rate of progression of experimental diabetic neuropathy. Neurology 1990; 40: 1446-1449.

12. Ward KK, Low PA, Schmelzer JD, Zochodne DW. Prostacyclin and noradrenaline in peripheral nerve of chronic experimental diabetes in rats. Brain 1989; 112: 197-208.

13. Cameron NE, Cotter MA, Dines KC, Robertson S, Cox D. The effects of evening primrose oil on nerve function and capillarization in streptozotocin diabetic rats: modulation by the cyclo-oxygenase inhibitor flurbiprofen. Br J Pharmacol 1993; 109 ; 972-979.

14. Cameron NE, Cotter MA, Dines KC, Maxfield EK. Pharmacological manipulation of vascular endothelium function in non-diabetic and streptozotocin diabetic rats: effects on nerve conduction, hypoxic resistance and endoneurial capillarization. Diabetologia 1993; 36: 516-522.

15. Brooks PM, Day RO. Nonsteroidal anti-inflammatory drugs - differences and similarities. N Engl J Med 1991; 324: 1716-1725.

16. Cameron NE, Cotter MA, Ferguson K, Robertson S, Radcliffe MA. Effects of chronic alpha-adrenergic receptor blockade on peripheral nerve conduction, hypoxic resistance, polyols, $\mathrm{Na}^{+}-\mathrm{K}^{+}$ATPase activity, and vascular supply in STZ-D rats. Diabetes 1991; 40: 1652-1658.

17. Robertson S, Cameron NE, Cotter MA. The effect of the calcium antagonist nifedipine on peripheral nerve function in streptozotocin-diabetic rats. Diabetologia 1992; 35: 1113-1117. 